\title{
NUMBER STICKS MEDIA FOR DEVELOPING BASIC CALCULATION SKILLS IN EARLY CHILDREN
}

\author{
Mohammad Archi Maulyda ${ }^{1}$, Vivi Rachmatul Hidayati ${ }^{2}$ \\ ${ }^{1}$ Universitas Mataram, ${ }^{2}$ Universitas Mataram \\ archimaulyda@unram.ac.id, vivirachma@unram.ac.id
}

\begin{abstract}
ABSTRAK
Penelitian ini bertujuan untuk mengetahui dapat tidaknya mengembangkan kemampuan berhitung permulaan pada anak Kelompok A TK PGRI 04 Kalibatur, Kecamatan Kalidawir, Kabupaten Tulungagung, menggunakan media stik angka. Jenis penelitian ini adalah Penelitian Tindakan Kelas (PTK) dengan model yang dikembangakn oleh Kemmis dan Mc Taggart. Subjek penelitian ini adalah 13 anak kelompok A. Teknik pengumpulan data yang digunakan adalah observasi dan dokumentasi sedangakan instrumen yang digunakan berupa lembar penilaian anak dan lembar observasi guru. Teknik analisis data yang digunakan teknik kuantitatif komparatif. Pada siklus I persentase ketuntasan sebanyak 30,8\%, siklus II sebanyak $61,5 \%$, dan siklus III sebanyak $92,3 \%$. Kesimpulan hasil penelitian ini adalah pembelajaran menggunakan media stik angka dapat mengembangkan kemampuan berhitung permulaan pada anak Kelompok A TK PGRI 04 Kalibatur Kecamatan Kalidawir Kabupaten Tulungagung Tahun Pelajaran 2020/2021.
\end{abstract}

Kata Kunci: Media Manipulatif, Stik Angka, Berhitung Awal, Anak

\begin{abstract}
This study aims to determine whether or not to develop preliminary numeracy skills in Group A children TK PGRI 04 Kalibatur, Kalidawir District, Tulungagung Regency, using number stick media. This type of research is a Classroom Action Research (PTK) with a model developed by Kemmis and Mc Taggart. The subjects of this study were 13 children in group A. The data collection techniques used were observation and documentation while the instruments used were child assessment sheets and teacher observation sheets. The data analysis technique used is comparative quantitative technique. In the first cycle the percentage of completeness was $30.8 \%$, the second cycle was $61.5 \%$, and the third cycle was $92.3 \%$. The conclusion of the results of this study is that learning using number stick media can develop initial numeracy skills in Group A children of TK PGRI 04 Kalibatur, Kalidawir District, Tulungagung Regency, 2020/2021 Academic Year.
\end{abstract}

Keywords: Manipulative Media, Number Sticks, Early Counting, Children

\section{INTRODUCTION}

Early childhood education (PAUD) is a coaching effort aimed at children from birth to six years of age child. Kindergarten is one of the formal early childhood education programs (Gaspar et al., 2018). One aspect of development that needs to be developed from an early age is the aspect of cognitive development (Reuter et al., 2015). According to Faradillah (2018), cognitive is a thought process, namely the ability of individuals to connect, assess, and consider an event or event. According to Cera et al. (2014), the cognitive abilities of children aged four and five years are as follows: counting and 
touching four or more objects, realizing some numbers and letters, and suggesting a sequence of numbers up to ten.

The ability to count is one of the elements included in cognitive development. Ayuni \& Setiawati (2019) says that counting is a way of learning about the names of numbers, then using the names of these numbers to identify the number of objects. Counting in Kindergarten is expected not only with cognitive abilities, but also mental, social and emotional readiness. In early childhood, counting activities can also be called preliminary counting. Yusnia (2018) states that the initial numeracy ability is the ability that each child has to develop his abilities, the characteristics of his development starting from the environment closest to him. The line of development the child's ability, it can increase to the stage of understanding the number, which is related to addition and subtraction (Maulyda et al., 2019).

According to Piaget (in Hidayati et al., 2020), the goal of learning mathematics for early childhood is logico-mathematical learning or learning to think logically and mathematically in a fun and uncomplicated way. Suherman (2017) reveals the principles of counting in early childhood including making fun lessons, getting children to be directly involved, building desire and confidence in adjusting counting, respecting children's mistakes and not punishing them, focusing on what children achieve. Kaya \& Deniz (2020) argues that counting in Kindergarten should be done through three stages of numeracy mastery, namely mastery of concepts, the transition period, and symbols. According to Triana \& Zubainur (2019), the main benefit of introducing mathematics, including arithmetic, is developing aspects of children's development and intelligence by stimulating the brain to think logically and mathematically.

According to Schmidt (2015) number media stick is one of the efforts to develop the ability to understand numbers in children. Media number sticks can be done through game activities, mentioning number sequences and recognizing number symbols, connecting numbers with their writing. One of the efforts that teachers must make is to use media (props) that are more creative and innovative (Herdani et al., 2018). The more creative use of media is expected to attract the attention of students, so that children are more motivated and enthusiastic in carrying out learning. Improving the ability to count early in early childhood will not run smoothly if it is not supported by the right media in its implementation in order to improve early counting skills for early childhood. According to Sari \& Gunawan (2018), media is any tool that can be used as a channel for messages to 
achieve teaching goals. According to Farihah (2017), there are several types of media, namely graphic media, audio media, and silent projection media.

In the learning process, there are many benefits from the media. According to Herawati (2016), the benefits of learning media both in general and specifically are as a learning tool for teachers and learners. Therefore, the media used must be interesting and innovative because learning media has an important role in achieving the goal of increasing early childhood numeracy skills. However, in reality, there are still institutions whose initial numeracy skills are still underdeveloped. To strengthen this data, researchers made preliminary observations in Group A TK PGRI 04 Kalibatur, Kalidawir District, Tulungagung Regency, 2020/2021Academic Year.

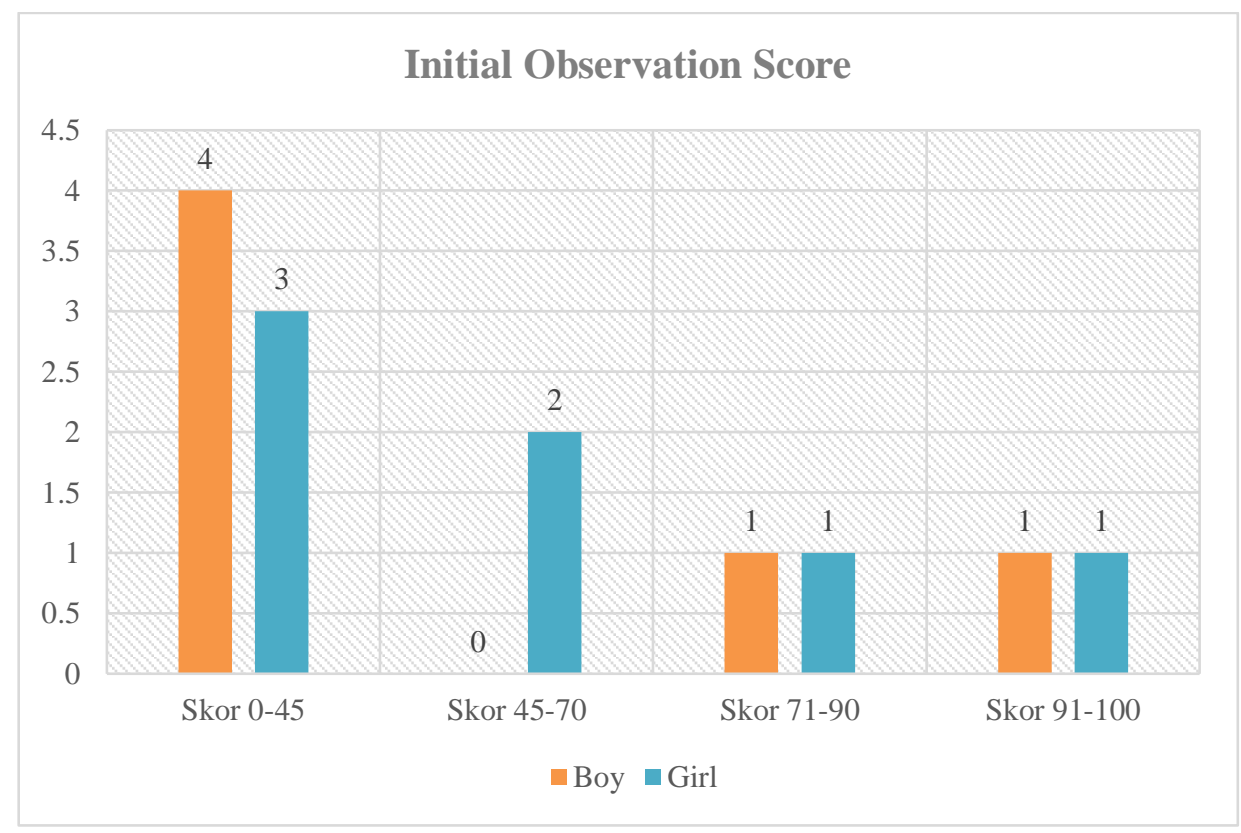

Figure 1 Preliminary Study Results

Based on the results of preliminary observations in Group A TK PGRI 04 Kalibatur, which amounted to 13 children consisting of 6 boys and 7 girls, it is known that the early counting skills of the children there are still underdeveloped. The cause of the inadequate process of learning to start counting there is that the learning media used by the teacher is less attractive so that the child is less enthusiastic during the learning process. A teacher must strive to make learning media that is attractive and innovative so that it can generate motivation and interest in children so that children learn such as playing and learning objectives can be achieved optimally.

Departing from these problems, it is necessary to improve to improve the ability to count beginning children. In improving the initial numeracy skills, it is necessary to have 
varied, fun, and contain the essence of playing, for example by using number sticks as the media. The number stick is a medium that replaces the "numeric block" created by Montessori in 1909. This media is made of wood in a rectangular shape. With the media of number sticks, children can learn to count while playing.

\section{METHOD}

\section{Research Design}

In this research, the type of research used is participatory collaborative classroom action research. Hake (2007) defines that participatory classroom action research is an activity with the involvement of other parties outside the researcher in conducting research. The research model chosen is the model developed by Kemmis and Mc. Taggart, developed from the thoughts of Setyosari (2013), which describes the PTK as a series of spiral-shaped steps.

\section{Population and Sample}

The population is all the people present in the research setting. The population of this study were all children in TK PGRI 04 Kalibatur, Kalidawir District, Tulungagung Regency, 2020/2021 Academic Year. The sample is part of the population that will be the research subject. The sample of this study were 13 children in group A consisting of 6 boys and 7 girls.

\section{Data collection and instruments}

In this study, the data collection techniques used were:

a. Observation is a technique of collecting data by observing every ongoing event and recording it with observation tools about the things to be observed or researched.

b. Documentation in this study uses photos and portfolios of learning activities at each stage of the cycle which are complementary to information or evidence that these activities have been carried out.

In this study, the instruments used were as follows:

a. This learning activity observation sheet is used to assess the author's performance during the learning process. The observation sheet contains a list of all aspects to be observed, so that the observer only has to give a mark on the aspects observed. There are 7 aspects that are observed, namely:

1) The appearance of the teacher in delivering learning

2) Management of learning activities by teachers 
3) The teacher opens the lesson

4) Mastery of learning materials by the teacher

5) The ability of teachers to use learning models / approaches / methods / strategies

6) The use of learning media by the teacher

7) The teacher's ability to develop children's character

b. Child Ability Assessment Sheet On this child assessment sheet, the researcher only gives a checklist on the assessment sheet with an indicator that the child can count numbers 1 to 10 correctly.

\section{Data Analysis}

The data analysis used in this study is a comparative quantitative technique, which is to determine the comparison of children's abilities or children's learning completeness before and after the research action is carried out. The data analysis steps are as follows:

1. Calculating the percentage of children who get 1 star, 2 star, 3 star and 4 stars with the formula:

$$
P=\frac{f}{N} \times 100 \%
$$

Information:

$\mathrm{P}=$ Percentage of children according to ability

$\mathrm{f}=$ The number of children according to the ability value

$\mathrm{N}=$ Total number of children

2. Comparing the completeness of learning (the percentage of children who get at least 3 stars) between the time before the action is carried out with after the first cycle, the second cycle of action, and the third cycle of action.

The criterion for the success of the action is an increase in learning completeness (after the action cycle III learning completeness reaches at least $80 \%$ ).

\section{Assessment rubric}

a. (Æ): Children cannot count the numbers 1 to 10 even though they have been assisted by the teacher.

b. (æঞ): Children can count numbers 1 to 10 with the help of the teacher.

c. (急): Children can count numbers 1 to 10 without the help of the teacher.

d. (急范): Children can count numbers 1 to 10 correctly without the help of the teacher. 


\section{RESULT AND DISCUSSION}

\section{Result}

Cycle I

Cycle I was held on Thursday, April 5 2020. In cycle I the theme was taken, namely "Communication Equipment" and the sub theme "Radio". The results of the first cycle were 4 children with a one star value ( $\circledast$ ) with a percentage of $30.8 \%, 5$ children with a two star value (æঞ) with a percentage of $38.4 \%$, and 4 children with a three star value (※æঞ) with a percentage of $30.8 \%$.

Cycle II

Cycle II was held on Thursday, April 12, 2018. The theme taken was "My Country" and the sub theme "Country Flag". The results achieved in cycle II were that there were 2 children with a one star value ( $\mathbb{*}$ ) with a percentage of $15.3 \%, 3$ children with a two star

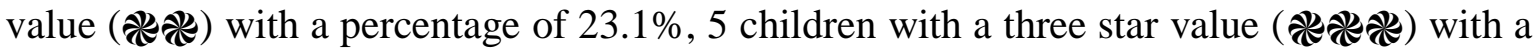
percentage of $38.5 \%$, and 3 children with a four-star rating (悉急) with a percentage of $23.1 \%$.

\section{Cycle III}

Cycle III was held on Thursday, April 19 2018. The theme taken was "My Country" and the sub theme "President and Vice President". The results achieved in cycle III were that there were 1 child with a two star value (※) with a percentage of $7.7 \%, 7$

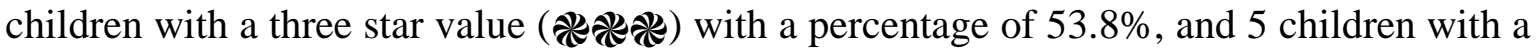
four star value. (悉悉) with a percentage of $38.5 \%$.

\section{Discussion}

The increase in numeracy skills at the beginning of group A TK PGRI 04 Kalibatur can be seen by comparing the percentage results from cycle I to cycle III. The percentage results obtained, in cycle II has increased by $30.7 \%$ compared to the results in cycle I. In cycle II, the percentage of children's learning completeness is $61.5 \%$ so there has been an increase of $30.7 \%$. In the third cycle the percentage of children's learning completeness was $92.3 \%$ so that there was an increase of $30.8 \%$. The following table presents the results of children's abilities during the three cycles:

Table 1 Recapitulation of Children's Ability Results from Cycle I to Cycle III

\begin{tabular}{ccc}
\hline No & Action & Percentage of Completeness \\
\hline 1 & Cycle I & $30,8 \%$ \\
2 & Cycle II & $61,5 \%$ \\
3 & Cycle III & $92,3 \%$ \\
\hline
\end{tabular}




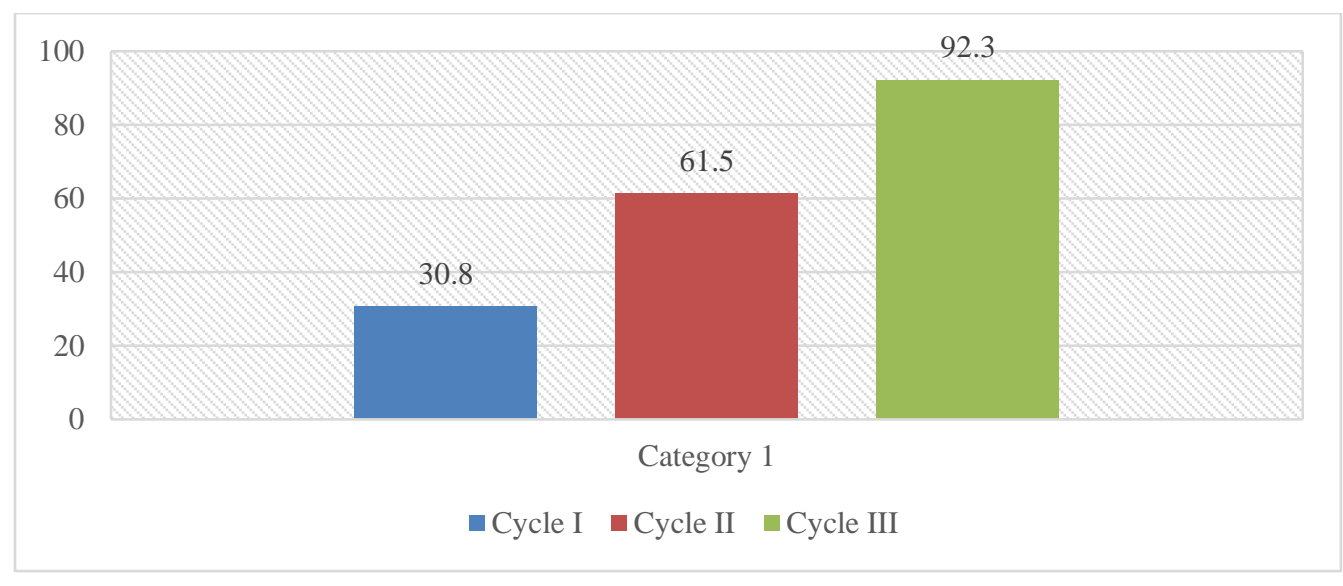

Figure 2 Learning Completeness

Based on the tables and graphs above, learning completeness can be achieved in cycle III with a percentage of $92.3 \%$ of the success criteria of at least $80 \%$. In addition, it can be seen that the child's initial numeracy skills have always increased in each cycle. This means that using number stick media can help children to be able to develop their abilities optimally. This is in accordance with the opinion of Rusmini \& Surya (2017) that early childhood learning adopts a play-while-learning or learning-while-playing approach. Through this media, the writer will also find it easier to convey the material because there are real objects that can be shown to children. This is in accordance with the opinion of Bartholdsson (2020) that kindergarten teachers should use various real objects in the learning process in children. These various real objects can be objects from nature, game tools and so on. Media number stick in

This research is made as attractive as possible to attract children's attention. In addition, before the child progresses, the writer and the child make an agreement regarding the rules of the game first so that the child becomes more disciplined and does not disturb other friends who are progressing. This agrees with Simanjuntak \& Siahaan (2018) that the provision of rules aims to equip children with approved behavior guidelines in certain situations. After seeing the results of the data on the percentage of learning completeness of children's beginning numeracy skills as stated in the reflection cycle III, it can be seen that learning using number stick media can improve the initial numeracy skills of group A children TK PGRI 04 Kalibatur, Kalidawir District, Tulungagung Regency, 2020/2021 Academic Year, so that the hypothesis which reads "learning using number stick media can develop the initial numeracy skills of group A TK PGRI 04 Kalibatur, Kalidawir District, Tulungagung Regency 2020/2021 Academic Year" is acceptable. 


\section{CONCLUSION}

After carrying out the actions from cycle I to cycle III, it can be seen that the percentage of completeness of learning early counting abilities in children increases from cycle to cycle. This can be seen from the results of calculating the percentage of learning completeness. In the first cycle, the children who met the learning completeness criteria were $30.8 \%$. In cycle II, children who met the learning completeness criteria were $61.5 \%$ so that there was an increase of $30.7 \%$, and in cycle III, children who met the learning completeness criteria were $92.3 \%$ so that there was an increase of $30.8 \%$. Based on the results of the research and discussion above, it can be concluded that learning using number stick media can develop initial numeracy skills in Group A children TK PGRI 04 Kalibatur, Kalidawir District, Tulungagung Regency for the 2020/2021Academic Year.

\section{RECOMMENDATION}

In addition, researchers also formulated some research suggestions as follows: (1) Teachers should be able to choose the right media for learning. For example, using number stick media to develop children's abilities in early counting and increasing children's enthusiasm during learning activities, so that children's learning outcomes will be better; (2) Schools must be wise in determining policies in managing learning and providing qualified facilities for the implementation of effective and efficient learning. The use of number stick media in learning can be used as an alternative learning media to help develop early numeracy skills in children.

\section{REFERENCES}

Ayuni, D., \& Setiawati, F. A. (2019). Kebun Buah Learning Media for Early Childhood Counting Ability. Jurnal Obsesi: Jurnal Pendidikan Anak Usia Dini, 3(1), 1. https://doi.org/10.31004/obsesi.v3i1.128

Bartholdsson, A. (2020). "When there is a book to stick to": teacher professionalism and manual-based programmes in two Swedish early childhood education settings. Education Inquiry, 14(3), 1-18. https://doi.org/10.1080/20004508.2020.1725373

Cera, R., Mancini, M., \& Antonietti, A. (2014). Relationships between Metacognition, Self-efficacy and Self-regulation in Learning. ECPS - Educational, Cultural and Psychological Studies, 1(7), 115-141. https://doi.org/10.7358/ecps-2013-007-cera

Faradillah, A. (2018). Analysis of Mathematical Reasoning Ability of Pre-Service Mathematics Teachers in Solving Algebra Problem Based on Reflective and Impulsive Cognitive Style. Formatif: Jurnal Ilmiah Pendidikan MIPA, 8(2). https://doi.org/10.30998/formatif.v8i2.2333

Farihah, H. (2017). Mengembangkan Kemampuan Berhitung Anak Usia Dini Melalui Kegiatan Bermain Stick Angka. Jurnal Teladan, 3(2), 12-33.

Gaspar, T., Cerqueira, A., Branquinho, C., \& Matos, M. G. (2018). The Effect of a Social- 
Emotional School-Based Intervention upon Social and Personal Skills in Children and Adolescents. Journal of Education and Learning, 7(6), 57-66. https://doi.org/10.5539/jel.v7n6p57

Hake, R. . (2007). Handbook of Design Research Methods in Mathematics, Science, and Technology Education (1st ed.). SAGE Publication.

Herawati, S. (2016). Pemanfaatan media pembelajaran gambar berseri untuk meningkatkan kemampuan menulis karangan sederhana pada siswa kelas II. Widyagogik, 3(3).

Herdani, T. P., Sartono, N., \& Evriyani, D. (2018). Development of Modified Monopoly Game as a Learning Media On Endocrine System (Research and Development at Senior High School 1 Jakarta). BIOSFER: JURNAL PENDIDIKAN BIOLOGI, 8(1), 20-28. https://doi.org/10.21009/biosferjpb.8-1.3

Hidayati, V. R., Maulyda, M. A., Gunawan, G., Rahmatih, A. N., \& Erfan, M. (2020). System of Linear Equation Problem Solving: Descriptive-Study about Students' Mathematical Connection Ability. Journal of Physics: Conference Series, 1594, 012042. https://doi.org/10.1088/1742-6596/1594/1/012042

Kaya, İ., \& Deniz, M. E. (2020). The effects of life skills education program on problem behaviors and social skills of 4-year-old preschoolers. Elementary Education Online, 19(2), 612-623. https://doi.org/10.17051/ilkonline.2020.692983

Maulyda, M. A., Hidayati, V. R., Rosyidah, A. N. K., \& Nurmawanti, I. (2019). Problemsolving ability of primary school teachers based on Polya's method in Mataram City. PYTHAGORAS: Jurnal Pendidikan Matematika, 14(2), 139-149. https://doi.org/https://doi.org/10.21831/pg.v14i2.28686

Reuter, T., Schnotz, W., \& Rasch, R. (2015). Drawings and Tables as Cognitive Tools for Solving Non-Routine Word Problems in Primary School. American Journal of Educational Research, 3(11), 1387-1397.

Rusmini, \& Surya, E. (2017). The Effect of Contextual Learning Approach to Mathematical Connection Ability and Student SelfConfidence Grade Viii Smp Negeri 8 Medan. International Journal of Sciences: Basic and Applied Research (IJSBAR), 35(2), 249-262.

Sari, A. M., \& Gunawan, I. (2018). Developing Physics Monopoly Game Learning Media for Light and Optical Devices. Jurnal Ilmiah Pendidikan Fisika Al-Biruni, 7(1), 7189. https://doi.org/10.24042/jipfalbiruni.v7i1.2564

Schmidt, S. J. (2015). Make It Stick: The Science of Successful Learning. Journal of Food Science Education, 7(1), 67-78. https://doi.org/10.1111/1541-4329.12075

Setyosari, P. (2013). Metode Penelitian Pendidikan \& Pengembangan. Prenadamedia group.

Simanjuntak, F., \& Siahaan, H. (2018). Upaya Meningkatkan Kemampuan Berhitung Permulaan Menggunakan Bahan Alam. Atfālunā: Journal of Islamic Early Childhood Education, 1(2), 47-52. https://doi.org/10.32505/atfaluna.v1i2.921

Suherman, W. S. (2017). Pengembangan "Majeda" Berbasis Dolanan Anak untuk Pengoptimalan Tumbuh Kembang Siswa Taman Kanak-kanak. Jurnal Cakrawala Pendidikan, 36(2). https://doi.org/10.21831/cp.v36i2.13542

Triana, M., \& Zubainur, C. M. (2019). Students 'Mathematical Communication Ability through the Brain-Based Learning Approach using Autograph. Journal of Research and Advances in Mathematics Education, 4(1), 1-10.

Yusnia, D. (2018). Analysis The Ability of Students Problem-Solving on Counting Operations of Algebra Form. MUST: Journal of Mathematics Education, Science and Technology, 3(1), 1. https://doi.org/10.30651/must.v3i1.1017 